\title{
Localization of Cellulase Components in Pseudomonas sp. Isolated from Activated Sludge
}

\author{
By K. RAMASAMY AND H. VERACHTERT* \\ Laboratory of Industrial Microbiology and Biochemistry, University of Louvain, \\ Kard. Mercierlaan, 92, 3030 Heverlee (Leuven), Belgium
}

(Received 20 March 1979; revised 7 September 1979)

\begin{abstract}
The localization of cellulase components in a Pseudomonas sp. isolated from activated sludge was studied. Endoglucanases were found in the culture media during growth on cellulose but not on cellobiose. Gel filtration and electrophoresis indicated that the extracellular enzyme contained two components, EI and EII. During growth on both substrates intracellular endoglucanases and aryl- $\beta$-glucosidases were formed. Late-exponential phase organisms from media containing cellulose or cellobiose were subjected to osmotic shock treatment or to spheroplast formation. Osmotic shock fluid contained endoglucanases and aryl- $\beta$-glucosidases. Spheroplast formation also released these enzymes. The glucosidases could be separated into aryl- $\beta$-glucosidase I and aryl- $\beta$-glucosidase II by ion-exchange chromatography. Endoglucanase was located differently on the cell surface depending on whether the growth substrate was cellulose or cellobiose. The cytoplasm contained another endoglucanase and aryl- $\beta$-glucosidase I. None of the enzymes hydrolysed avicel, but all except aryl- $\beta$-glucosidase III hydrolysed carboxymethylcellulose. All aryl- $\beta$-glucosidases, but none of the endoglucanases, hydrolysed cellobiose.
\end{abstract}

\section{INTRODUCTION}

There have been several reports on the microbial hydrolysis of cellulose and, especially in the last decade, many papers have appeared on cellulose, cellulolysis and cellulases. Most of them were concerned with cellulolysis by fungi, mainly Trichoderma reesei $(T$. viride) or its mutants. Cellulase is not a single enzyme, but an enzyme complex consisting of endo-1,4$\beta$-glucanase, exo-1,4- $\beta$-glucanase and cellobiase activities. With fungi, all the enzymes required to hydrolyse native cellulose may be found extracellularly (Reese, 1977). To obtain cellulolysis with bacteria, growing organisms are required; this is probably because some components of cellulase remain bound to them (Reese, 1977). In some systems, such as the rumen, bacteria are the predominant group of cellulose-splitting organisms. We have also demonstrated that about $70 \%$ of the cellulose entering a waste-water treatment plant can be degraded by aerobic bacteria (Verachtert \& Ramasamy, 1979). Some cellulolytic bacteria were isolated and one Pseudomonas sp. was shown to degrade $60 \%$ of native cellulose in vitro in $5 \mathrm{~d}$. It secretes extracellular endoglucanases and has bound endoglucanase and aryl- $\beta$-glucosidase activity (Bevers, 1976). With the exception of work on the localization of, mainly, endoglucanases in fungi (Berg \& Pettersson, 1977) and bacteria (Berg, 1975; Yamane et al., 1970) there is little published evidence on the nature and localization of bacterial cellulolytic enzymes. Until now it has also been difficult to obtain cell-free cellulolysis with bacterial enzymes (Berg et al., 1972; Bevers, 1976). For these reasons we have studied the localization of cellulase components using the Pseudomonas sp. isolated from activated sludge. 


\section{METHODS}

Organism and its culture. A Pseudomonas sp. isolated from activated sludge (Bevers, 1976) and used in an earlier study (Ramasamy et al., 1979) was maintained on agar slants containing salts (Berg et al., 1972) and covered with sterile pieces of Whatman no. 1 paper. For growth in liquid media, a loopful of organisms was transferred from the slants to test tubes containing the same salts solution $(8 \mathrm{ml})$ and a strip of filter paper $(6 \times 1 \mathrm{~cm})$ immersed for about two-thirds of its length, or $8 \mathrm{ml}$ mineral salts solution and $0.5 \%(\mathrm{w} / \mathrm{v})$ cellobiose. After incubation at $28{ }^{\circ} \mathrm{C}$ for $70 \mathrm{~h}$ the contents of the tubes were homogenized by shaking and the resulting slurry from one tube was used to inoculate a $500 \mathrm{ml}$ Erlenmeyer flask containing $100 \mathrm{ml}$ mineral salts solution and $1 \mathrm{~g}$ microcrystalline cellulose powder or $0.5 \%(\mathrm{w} / \mathrm{v})$ cellobiose. After $48 \mathrm{~h}$ incubation in the dark at $28^{\circ} \mathrm{C}$ on a reciprocal shaker $\left[110\right.$ strokes $\mathrm{min}^{-1}$, the aeration corresponding to a sulphite oxidation rate of $22 \mathrm{mmol} \mathrm{l}^{-1} \mathrm{~h}^{-1}$, as determined by the method of Cooper et al. (1944)], the contents were again homogenized and used as inoculum. The final growth medium contained $5 \%(\mathrm{v} / \mathrm{v})$ of this inoculum. For the study of enzyme localization, organisms were grown in 31 flat-bottomed round flasks containing $500 \mathrm{ml}$ mineral salts solution and $1 \%(\mathrm{w} / \mathrm{v})$ microcrystalline cellulose or $0.5 \%(\mathrm{w} / \mathrm{v})$ cellobiose. Organisms were harvested in the late-exponential phase and collected by allowing the cellulose to settle in a glass cylinder for about $1 \mathrm{~h}$ (Berg, 1975). The settled solids were resuspended several times in sterile salts solution (as used for growth) and the combined supernatants were centrifuged at $10000 \mathrm{~g}$ for $15 \mathrm{~min}$. Organisms were washed three times with McIlvaine buffer ( $\mathrm{pH} 7 \cdot 0,0.02 \mathrm{M})$.

Growth on cellulose was followed by determination of cellular proteins and residual cellulose (Van Oevelen et al., 1975).

Preparation of sub-cellular fractions (Fig. 1). Sub-cellular fractions were obtained by osmotic shock or spheroplast formation by slight modifications of the methods of Kowit et al. (1976) and Yamane et al. (1971), respectively. The spheroplasts after lysis and organisms after osmotic shock were ruptured in a French pressure cell (Aminco, Silver Spring, Maryland, U.S.A.) at about $110 \mathrm{MPa}$. Total cell-bound enzymes were obtained after disruption in a Braun disruptor (B. Braun, Melsungen, West Germany). Cell suspension $(25 \mathrm{ml})$ was shaken five times for $1 \mathrm{~min}$ in the presence of $40 \mathrm{~g}$ glass beads $(0 \cdot 1$ to $0.3 \mathrm{~mm}$ diam.) and Tris $/ \mathrm{HCl}$ buffer $(33 \mathrm{~mm}, \mathrm{pH} 7 \cdot 5)$, under $\mathrm{CO}_{2}$ cooling. After centrifuging the mixture, the residues were washed with similar buffer and the supernatants were combined (Fig. 1).

Enzyme concentration. Enzymes contained in the different fractions were concentrated by $\left(\mathrm{NH}_{4}\right)_{2} \mathrm{SO}_{4}$ precipitation. The precipitates obtained between 20 and $80 \%$ saturation were dissolved in $5 \mathrm{ml} \mathrm{McIlvaine}$ buffer and dialysed against similar buffer $(0 \cdot 01 \mathrm{M}, \mathrm{pH} 7 \cdot 0)$. After dialysis, insoluble material was removed by centrifugation $(15000 \mathrm{~g} ; 10 \mathrm{~min})$ and the supernatants were stored at $-4{ }^{\circ} \mathrm{C}$.

Gel filtration. Extracellular enzymes were fractionated on Ultrogel Ac A44 (LKB) equilibrated with McIlvaine buffer $(0.05 \mathrm{M}, \mathrm{pH} 7.0)$ containing $5 \mathrm{~mm}$-sodium azide. Enzyme solution ( $5 \mathrm{ml}$ ) was applied to a column $(2.6 \times 36 \mathrm{~cm}$, Pharmacia K 26/40) and enzymes were eluted with McIlvaine buffer $(0.05 \mathrm{M})$ at a flow rate of $10 \mathrm{ml} \mathrm{h}^{-1}$. Fractions $(3 \mathrm{ml})$ were collected with a Gilson fraction collector and $200 \mu \mathrm{l}$ amounts were tested for enzyme activities and protein content.

Ion-exchange chromatography. Cell-bound enzymes were fractionated by ion-exchange chromatography. DEAE-Sephadex A-50 (Pharmacia) was equilibrated with McIlvaine buffer $(0.02 \mathrm{M}, \mathrm{pH} 7.0)$ in the Pharmacia K 26/40 column. Enzyme solution $(5 \mathrm{ml})$ was applied to the top of the column and eluted successively with $100 \mathrm{ml} 0.02 \mathrm{M}$-Mcllvaine buffer, $400 \mathrm{ml}$ of a NaCl $(0$ to $0.5 \mathrm{M})$ gradient in similar buffer, $200 \mathrm{ml}$ of $0.5 \mathrm{M}-$ $\mathrm{NaCl}$ in similar buffer, $400 \mathrm{ml}$ of a $\mathrm{NaCl}(0.5$ to $2 \mathrm{M})$ gradient in similar buffer and $200 \mathrm{ml}$ of $2 \mathrm{M}-\mathrm{NaCl}$. Gradients were produced by a gradient mixer (Pharmacia GM-1).

Polyacrylamide gel electrophoresis $(P A G E)$. Electrophoresis was used to separate and observe the aryl- $\beta$ glucosidases (Verachtert et al., 1978). PAGE was performed on Acrylophore (Pleuger, Belgrium) with $65 \times$ $9 \mathrm{~mm}$ gels containing $6 \%(\mathrm{w} / \mathrm{v})$ acrylamide at a constant current of $5 \mathrm{~mA}$ per gel (about $45 \mathrm{~min}$ ). The temperature during the run was maintained at $15^{\circ} \mathrm{C}$. For the direct observation of aryl- $\beta$-glucosidases, the substrate $o$-nitrophenyl- $\beta$-D-glucopyranoside was incorporated in the gel at a final concentration of $1 \mathrm{~mm}$. After electrophoresis, gels for direct observation of aryl- $\beta$-glucosidases were incubated at $37^{\circ} \mathrm{C}$ until sufficient $o$-nitrophenol had been liberated by the separated aryl- $\beta$-glucosidases to give visible yellow bands ( 5 to $15 \mathrm{~min}$ ). Parallel (control) gels were fixed in $\mathbf{1 2 . 5} \%(\mathrm{w} / \mathrm{v})$ trichloroacetic acid. After $45 \mathrm{~min}$ the fixed gels were stained with Coomassie brilliant blue G-250. Endoglucanases were also detected by slicing the gels ( $1 \mathrm{~mm}$ thick) and incubating the slices in $0.5 \mathrm{ml} 0.1 \%(\mathrm{w} / \mathrm{v})$ carboxymethylcellulose for $1 \mathrm{~h}$ at $37^{\circ} \mathrm{C}$. After incubation, the reducing sugars liberated were estimated by the method of Nelson (1944). By calculating the relative mobility and the slice number, the location of the enzyme protein was determined in the control gels after staining.

Enzyme assays. The endoglucanase (endo-1,4- $\beta$-glucanase; carboxymethylcellulase; EC 3.2.1.4) was determined according to the method of Selby \& Maitland (1965). The activity was assayed with Ostwald 


\section{BACTERIA}

(about $300 \mathrm{mg}$ protein, from 21 culture)

Suspended in Tris/ $\mathrm{HCl}$ buffer ( $33 \mathrm{~mm}, \mathrm{pH} 7.5)$

Centrifugation

$(10 \mathrm{~min}, 10000 \mathrm{~g})$

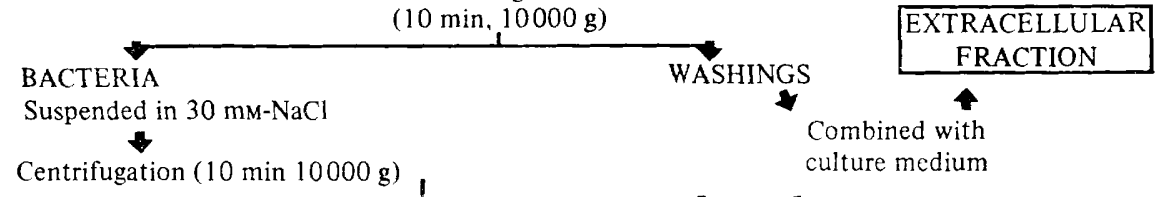

BACTERIA

WASHINGS

Suspended in $75 \mathrm{ml}$ Tris/HCl buffer (33 mM, pH 7.5)

$25 \mathrm{ml}$ CELL SUSPENSION

$+40 \%$ sucrose

+1 mM-EDTA

Shaken $\left(10 \mathrm{~min}, 25^{\circ} \mathrm{C}\right)$

Centrifugation

$(15 \mathrm{~min}, 10000 \mathrm{~g})$

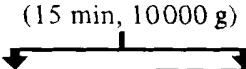

RESIDUE

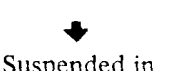

$25 \mathrm{ml} 2 \mathrm{~mm}-\mathrm{MgCl}_{2}$

Shaken $\left(10 \mathrm{~min}, 4^{\circ} \mathrm{C}\right)$

$\checkmark$

Centrifugation

(15 min, $15000 \mathrm{~g}$ )

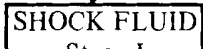

Stage I

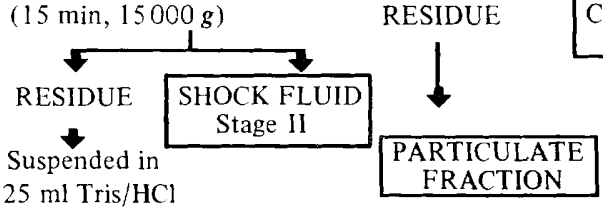

buffer

Ruptured in French<smiles>C1[As][As]1</smiles>

Centrifugation $(20 \mathrm{~min}, 30000 \mathrm{~g}$ )

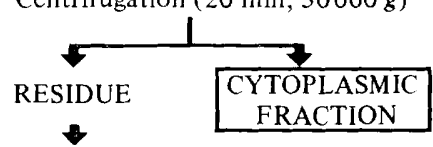

PARTICULATE

FRACTION

Fig. 1. General procedure for the fractionation of cellulolytic enzymes from Pseudomonas sp. Organisms from four flasks were pooled to start the fractionation. Enzymes of the particulate fraction were extracted further by disruption with a Braun homogenizer. Additional details are given in Methods.

viscometers at $30^{\circ} \mathrm{C}$. The reaction mixture contained $2.5 \mathrm{ml} \mathrm{McIlvaine} \mathrm{buffer}(0 \cdot 2 \mathrm{M}, \mathrm{pH} 7 \cdot 0), 5 \cdot 0 \mathrm{ml} 1 \%$ $\mathrm{w} / \mathrm{v})$ carboxymethylcellulose with $0.01 \%(\mathrm{w} / \mathrm{v})$ merthiolate as antimicrobial agent and $2.5 \mathrm{ml}$ of appropriately diluted enzyme solution. The reaction was started by adding the enzyme and the run out time (35 to $40 \mathrm{~s}$ for distilled water) of the solution was assayed at $15 \mathrm{~min}$ intervals. The enzyme activity was calculated as the increase in specific fluidity and one unit of activity was defined as the amount of enzyme producing an increase in the specific fluidity of $10^{-4} \mathrm{~min}^{-1}$. Reducing sugars released by this enzyme were determined 
by the method of Wood (1968) and one unit of activity was defined as the amount of enzyme capable of liberating an amount of reducing sugars equivalent to $1 \mu \mathrm{mol}$ glucose $\mathrm{min}^{-1}$.

The aryl- $\beta$-glucosidase (cellobiase; EC 3.2.1.21) assay was based on chromogenic $o$-nitrophenol release from $o$-nitrophenyl- $\beta$-D-glucopyranoside (Wood, 1968). Test tubes containing $1 \mathrm{ml} 5 \mathrm{~mm}$-o-nitrophenyl- $\beta$ D-glucopyranoside, $1 \mathrm{ml} \mathrm{Mcllvaine} \mathrm{buffer}(0.2 \mathrm{M}, \mathrm{pH} 7.0)$ and $2 \mathrm{ml}$ of appropriately diluted enzyme sample were incubated at $37^{\circ} \mathrm{C}$. After $1 \mathrm{~h}$ the reaction was terminated by the addition of $4 \mathrm{ml} \mathrm{NaOH} /$ glycine buffer $(0.4 \mathrm{M}, \mathrm{pH} \mathrm{10.8)}$. The absorbance of the liberated $o$-nitrophenol was measured at $425 \mathrm{~nm}$ and one unit of activity corresponded to the amount of enzyme capable of liberating $1 \mu \mathrm{mol} o$-nitrophenol $\mathrm{min}^{-1}$ under the assay conditions. Cellobiase was also determined by measuring the glucose released, by the glucose oxidase method (Biochemica test combination; Boehringer, West Germany) and by the method of Nelson (1944).

Protein contents were assayed according to the Lowry method with bovine serum albumin as standard or by ultraviolet absorbance.

Reaction products. Products obtained after incubation of different enzyme fractions with several substrates were determined by paper chromatography. The reaction mixture contained equal volumes of McIlvaine buffer $(0.02 \mathrm{M}, \mathrm{pH} 7.0), 1 \%(\mathrm{w} / \mathrm{v})$ substrate solution and diluted enzyme fraction. The mixture was incubated at $37^{\circ} \mathrm{C}$ and $1 \mathrm{ml}$ samples were removed at regular intervals. The enzyme was inactivated by heating on a boiling water bath for $10 \mathrm{~min}$. A sample $(100 \mu \mathrm{l})$ of the reaction mixture was then spotted on Whatman no. 3 paper $(30 \times 40 \mathrm{~cm})$ and the chromatograms were developed by ascending chromatography in butan-1-ol/ pyridine/water $(60: 40: 30$, by vol.) for $15 \mathrm{~h}$. Sugars were detected by the alkaline silver nitrate method of Trevelyan et al. (1950).

Chemicals. Cellulose powder MN 300 was from Machery Nagel \& Co., Duren, West Germany; carboxymethylcellulose Cellofas B 50 was from ICI, Scotland; cellobiose was from Koch-Light; dialysis tubing (Visking, size 6, 27/32 in) was from Medicell International, London. Gel electrophoresis chemicals (acrylamide, $N, N^{\prime}$-methylene bisacrylamide, $N, N, N^{\prime}, N^{\prime}$-tetramethylethylenediamine and ammonium persulphate) were obtained from Pleuger, Belgium. The substrate $o$-nitrophenyl- $\beta$-D-glucopyranoside for enzyme assays was from Fluka, Switzerland; for incorporation in the gel, the chromatographically pure product was obtained from BDH. All other chemicals were analytical grade reagents obtained from Merck or Sigma.

\section{RESULTS}

\section{Growth and enzyme synthesis}

The general pattern of cellulose degradation, growth and production of cellulolytic enzymes (Fig. 2) showed that maxima in extracellular endoglucanase and cell-bound aryl- $\beta$-glucosidase activities occurred at $2 \mathrm{~d}$. Bacteria from the late-exponential phase of growth were therefore used for fractionation.

\section{Extracellular cellulase components}

Enzyme activities of various fractions (Fig. 1) are shown in Table 1. Only endoglucanases were found in the culture medium. These enzymes were almost completely absent from cellobiose-grown organisms. Gel chromatography of the extracellular enzymes (Fig. 3) gave two distinct peaks of activity. PAGE indicated that fraction EI contained two proteins of which one had endoglucanase activity. Fraction EII contained only one protein and this had endoglucanase activity. Before gel chromatography of the extracellular enzymes five protein bands were detected by PAGE, two of them with endoglucanase activity. PAGE patterns are shown schematically in Fig. 3 and photographically in Fig. 7(a).

\section{Cell-bound cellulase components}

In the total cell-bound fraction, endoglucanase activity was present at similar levels after growth on cellulose or cellobiose (Table 1). When this fraction was submitted to ion-exchange chromatography (gel filtration did not separate the aryl- $\beta$-glucosidases, and endoglucanase and all the three aryl- $\beta$-glucosidases were eluted in a single peak), two peaks gave fractions containing endoglucanase activity (Fig. 4). Peak AI was eluted before the $\mathrm{NaCl}$ gradient was started. It also possessed aryl- $\beta$-glucosidase activity (aryl I). When the $\mathrm{NaCl}$ gradient was started, a second peak (AII) was eluted, which contained mainly aryl- $\beta$-glucosidase (aryl II) and some endoglucanase activity. Peak AIII was eluted above $0 \cdot 5 \mathrm{M}-\mathrm{NaCl}$ and 

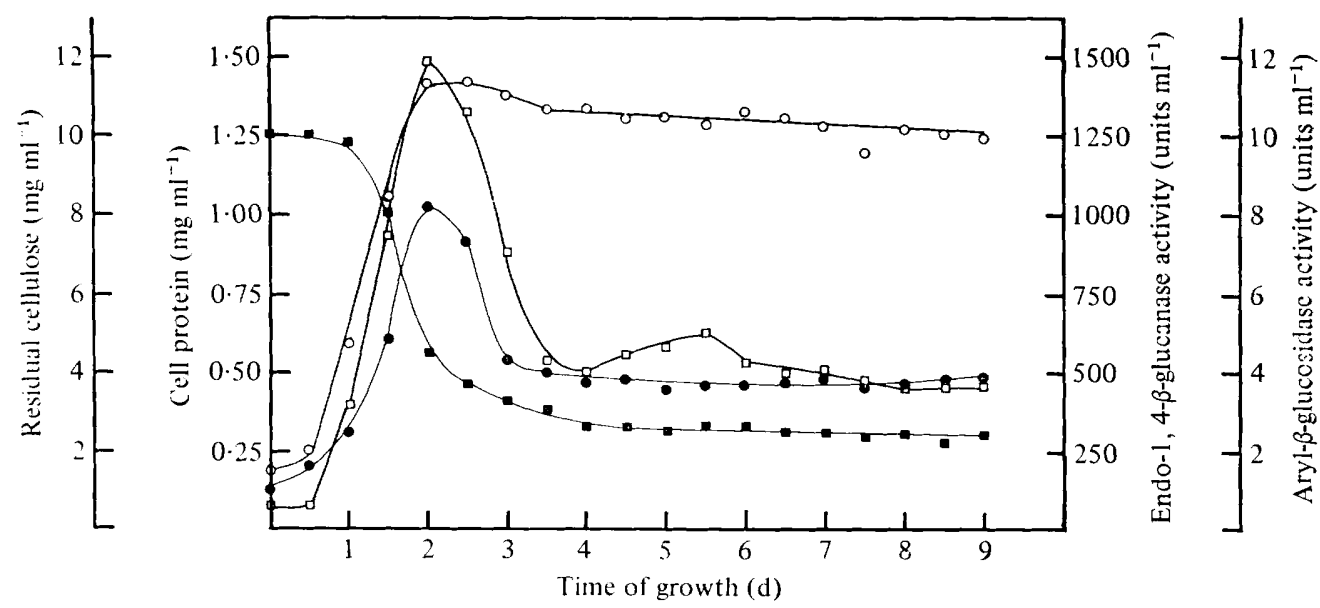

Fig. 2. Cellulose degradation, growth and enzyme production by Pseudomonas sp. isolated from activated sludge. Extracellular endoglucanase ( $\square$ ); cell-bound aryl- $\beta$-glucosidase (O); cell proteins (C); residual cellulose ( $\square$ ).

\section{Table 1. Distribution of extracellular and cell-bound endoglucanase and aryl- $\beta$-glucosidase activities of Pseudomonas $s p$.}

Bacteria were grown in $100 \mathrm{ml}$ medium containing cellulose or cellobiose as substrate. All results are expressed as units (defined in Methods) in fractions obtained from $100 \mathrm{ml}$ culture.

\begin{tabular}{|c|c|c|c|c|}
\hline \multirow[b]{2}{*}{ Fraction } & \multicolumn{2}{|c|}{$\begin{array}{l}\text { Endoglucanase activity } \\
\text { after growth on: }\end{array}$} & \multicolumn{2}{|c|}{$\begin{array}{l}\text { Aryl- } \beta \text {-glucosidase activity } \\
\text { after growth on: }\end{array}$} \\
\hline & Cellulose & Cellobiose & Cellulose & Cellobiose \\
\hline $\begin{array}{l}\text { Extracellular fraction } \\
\text { Total cell-bound fraction } \\
\text { Sub-cellular fractions }\end{array}$ & $\begin{array}{r}2150 \\
670\end{array}$ & $\begin{array}{r}15 \\
895\end{array}$ & $\begin{array}{r}0 \\
422\end{array}$ & $\begin{array}{r}0 \\
426\end{array}$ \\
\hline $\begin{array}{l}\text { 1. Osmotic shock } \\
\text { Shock fluid-stage I } \\
\text { Shock fluid-stage II } \\
\text { Cytoplasmic fraction } \\
\text { Particulate fraction }\end{array}$ & $\begin{array}{r}280 \\
20 \\
285 \\
95\end{array}$ & $\begin{array}{r}75 \\
440 \\
280 \\
75\end{array}$ & $\begin{array}{r}56 \\
116 \\
220 \\
50\end{array}$ & $\begin{array}{r}130 \\
110 \\
178 \\
42\end{array}$ \\
\hline $\begin{array}{l}\text { 2. Spheroplast formatio } \\
\text { Intra-wall fraction } \\
\text { Cytoplasmic fraction } \\
\text { Particulate fraction }\end{array}$ & $\begin{array}{l}295 \\
220 \\
120\end{array}$ & $\begin{array}{l}562 \\
245 \\
175\end{array}$ & $\begin{array}{l}202 \\
240 \\
190\end{array}$ & $\begin{array}{l}298 \\
120 \\
140\end{array}$ \\
\hline
\end{tabular}

contained only aryl- $\beta$-glucosidase (aryl III) activity. The three peaks also exhibited cellobiase activity when eluates were incubated with cellobiose. PAGE of the three peaks revealed that each fraction contained several proteins. However, in each peak only one protein had aryl- $\beta$-glucosidase activity. These three aryl- $\beta$-glucosidases could also be detected after PAGE of the total cell-bound fraction. Of the total aryl- $\beta$-glucosidase activity of the cells grown on cellulose, about 50\% was recovered in peak AI, $31 \%$ in AII and $16 \%$ in AIII. After growth on cellobiose, less aryl I (35\%) but more aryl III ( $28 \%)$ was observed; aryl II accounted for $30 \%$ of the total activity. PAGE patterns are shown schematically in Fig. 4 and photographically in Fig. $7(b)$.

To study the differential location of the enzymes observed in the total cell-bound fraction, the subcellular fractions obtained by osmotic shock were also submitted to ion-exchange chromatography. The shock fluid-stage I for cellulose-grown cells contained endoglucanase and aryl- $\beta$-glucosidase activities. PAGE indicated that the aryl- $\beta$-glucosidase was aryl III. 


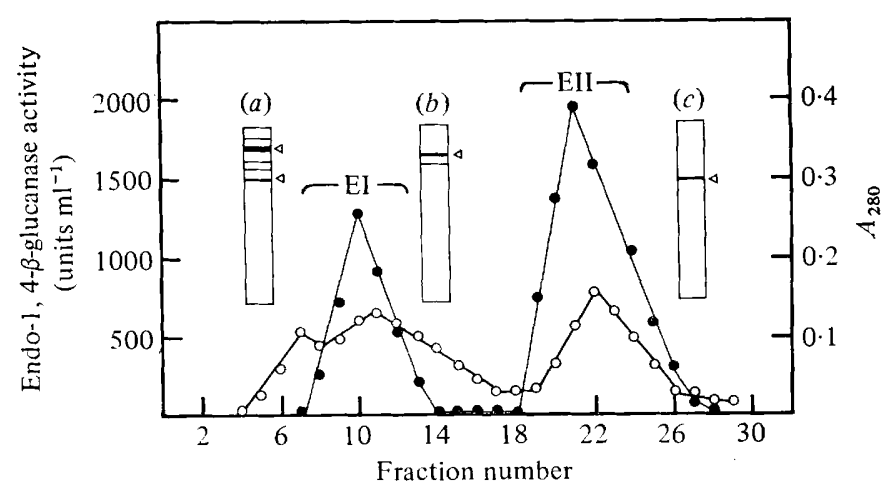

Fig. 3. Gel chromatography of the extracellular enzyme fraction. Fractions $(3 \mathrm{ml})$ were collected at a flow rate of $10 \mathrm{ml} \mathrm{min}{ }^{-1}$; other details are given in Methods. Endoglucanase activity in viscosity units (@); protein, $\mathrm{A}_{280}(\bigcirc)$. Insets show PAGE separation of $(a)$ crude extracellular fraction, $(b)$ fraction EI and $(c)$ fraction EII; open arrows indicate endoglucanase activity. See Fig. 7(a) for photographs of PAGE separations.

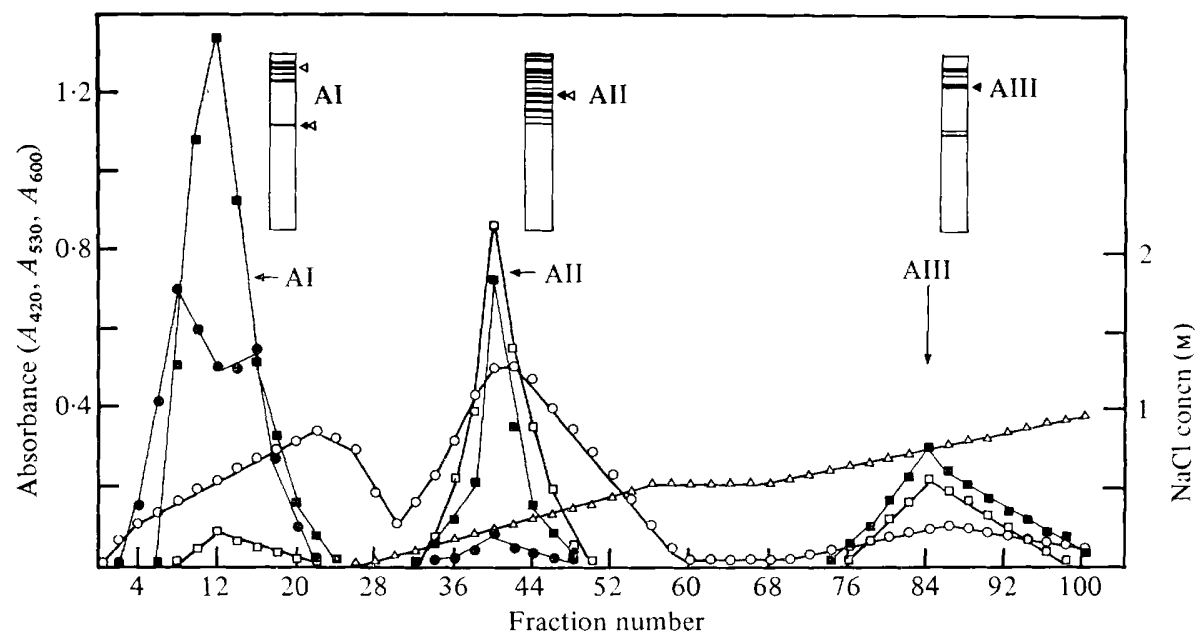

Fig. 4. Ion-exchange chromatography of total cell-bound enzymes from organisms grown on cellulose powder. A sample containing $70 \mathrm{mg}$ protein was applied to the column and $5 \mathrm{ml}$ fractions were collected; see Methods for elution details. Endoglucanase activity (reducing sugars released from carboxymethylcellulose), $A_{530}(\bigcirc)$; protein (Lowry), $A_{600}(\bigcirc)$; aryl- $\beta$-glucosidase activity (release of $o$-nitrophenol), $A_{420}(\square)$; cellobiase activity (glucose released from cellobiose), $A_{420}(\square)$; $\mathrm{NaCl}$ gradient $(\triangle)$. Insets show PAGE separation of the proteins contained in each peak; open arrows indicate endoglucanase activity and closed arrows indicate aryl- $\beta$-glucosidase activity. Similar separation patterns were obtained for cellobiose-grown organisms. See Fig. $7(b)$ for photographs of PAGE separations.

Ion-exchange chromatography confirmed this (Fig. 5a). An endoglucanase was recovered in the first protein peak and aryl III in the second peak after the $0.5 \mathrm{M}-\mathrm{NaCl}$ gradient was initiated. For cells grown on cellobiose, less endoglucanase and more aryl III was found. Shock fluid-stage II from the cells grown on cellulose contained little endoglucanase, traces of aryl III and more of aryl II (Fig. $5 b$ ). For cells grown on cellobiose, the endoglucanase activity was much higher. Aryl II and traces of aryl III were also observed (Table 1, Fig. $5 b$ ). PAGE of shock fluids I and II indicated that the endoglucanase observed in the two fractions was confined to a single protein band. 


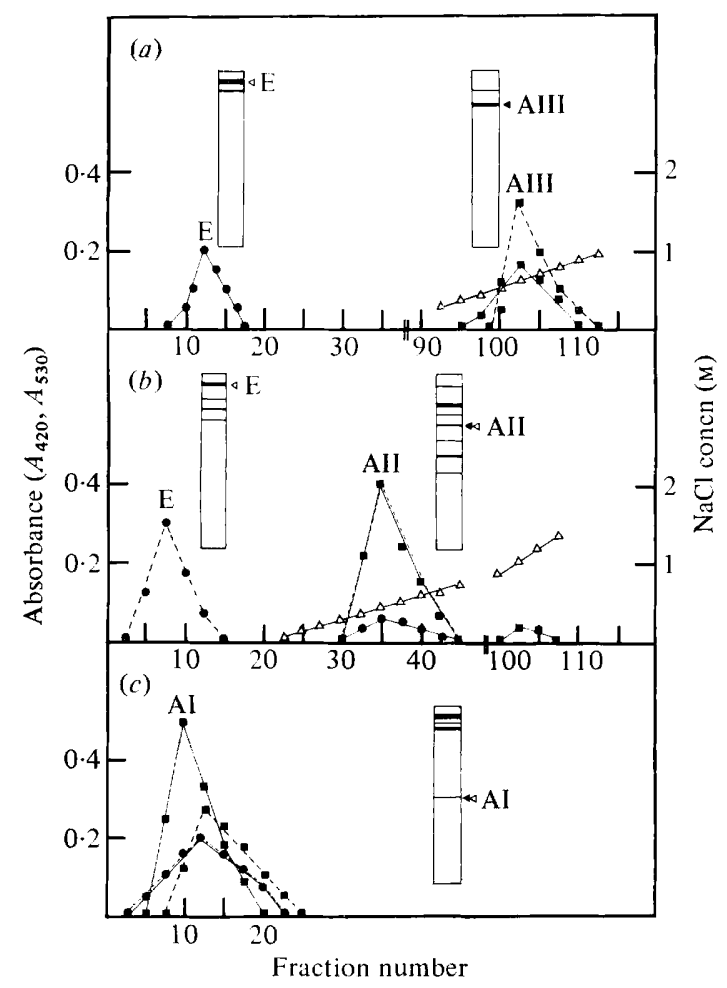

Fig. 5. Ion-exchange chromatography of the enzyme fractions obtained by osmotic shock treatment: $(a)$ shock fluid-stage I, $(b)$ shock fluid-stage II and $(c)$ cytoplasmic fraction. A sample containing $50 \mathrm{mg}$ protein was applied to the column and $5 \mathrm{ml}$ fractions were collected. Endoglucanase activity (reducing sugars released from carboxymethylcellulose), $A_{530}(\odot)$; aryl- $\beta$-glucosidase activity (release of $o$-nitrophenol), $A_{420}(\mathbf{a}) ; \mathrm{NaCl}$ gradient $(\triangle$ ). Activity for cellobiose-grown organisms (--); activity for cellulose-grown organisms (-). Insets are PAGE separations; open arrows indicate endoglucanase activity and closed arrows indicate aryl- $\beta$-glucosidase activity. See Fig. 7(c) for photographs of PAGE separations.

The cytoplasmic fraction showed endoglucanase and aryl- $\beta$-glucosidase activity. PAGE and ion-exchange chromatography indicated that the latter was aryl I (Fig. $5 c$ ). Similar results were observed for both cellulose- and cellobiose-grown cells.

These results were further checked by spheroplast formation, which demonstrated the presence of aryl II and aryl III together with endoglucanase in the intra-wall fraction (Fig. 6). Again the cytoplasmic fraction resulting from this procedure contained only aryl I and endoglucanase. Particulate fractions obtained by both methods contained some endoglucanase and aryl- $\beta$-glucosidase activity (Table 1). To extract the particulate-bound enzymes, this fraction was homogenized with a Braun disruptor using Tris/ $\mathrm{HCl}$ buffer (33 mM, pH 7.5) containing $1 \mathrm{mm-EDTA}$. Although the extracted enzymes were not sufficient for ion-exchange chromatography, PAGE revealed aryl II and aryl III in the fractions obtained after osmotic shock and all three aryl- $\beta$-glucosidases after spheroplast formation.

\section{Hydrolysis of substrates}

Endoglucanase and aryl- $\beta$-glucosidase fractions separated by ion-exchange chromatography were concentrated by $\left(\mathrm{NH}_{4}\right)_{2} \mathrm{SO}_{4}$ precipitation and tested for activity towards avicel, carboxymethylcellulose and cellobiose (Table 2). Avicel was not hydrolysed by any of the fractionated enzymes. Carboxymethylcellulose was hydrolysed by the extracellular endo- 


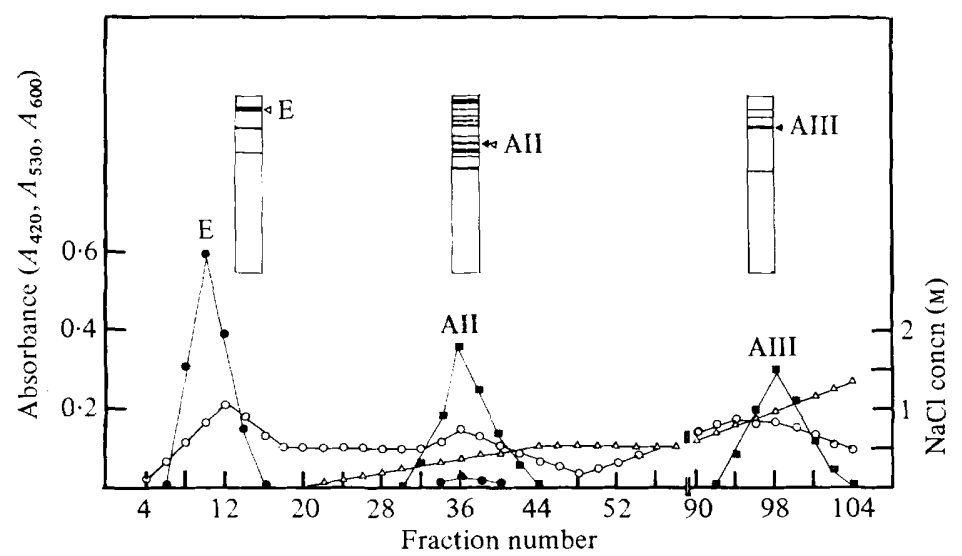

Fig. 6. Ion-exchange chromatography of the enzyme fractions obtained by lysozyme treatment: intra-wall fraction. A sample containing $50 \mathrm{mg}$ protein was applied to the column and $5 \mathrm{ml}$ fractions were collected. Endoglucanase activity (reducing sugars released from carboxymethylcellulose), $A_{530}(\bigcirc)$; aryl- $\beta$-glucosidase activity (release of $o$-nitrophenol), $A_{420}(\square) ; \mathrm{NaCl}$ gradient $(\Delta)$; protein (Lowry), $A_{600}(O)$. The cytoplasmic fractions obtained by the lysozyme treatment showed similar separations to those of Fig. 5(c). Insets are PAGE separations; open arrows indicate endoglucanase activity and closed arrows indicate aryl- $\beta$-glucosidase activity. See Fig. $7(d)$ for photographs of PAGE separations.

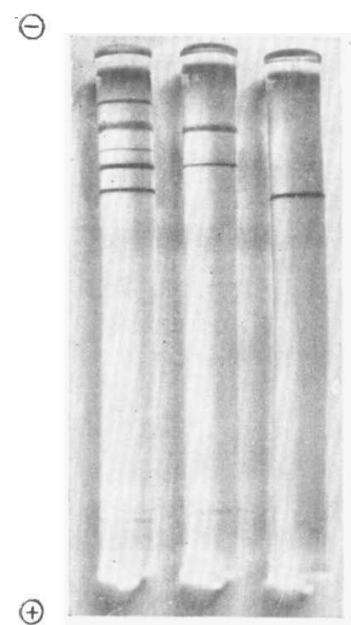

(a)

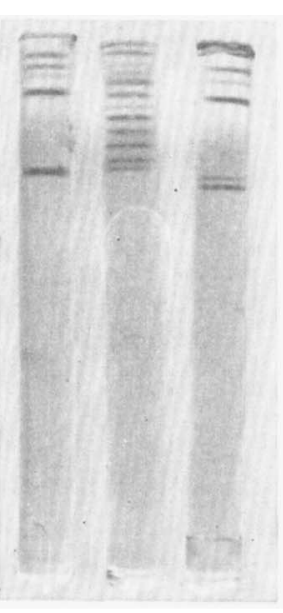

(b)

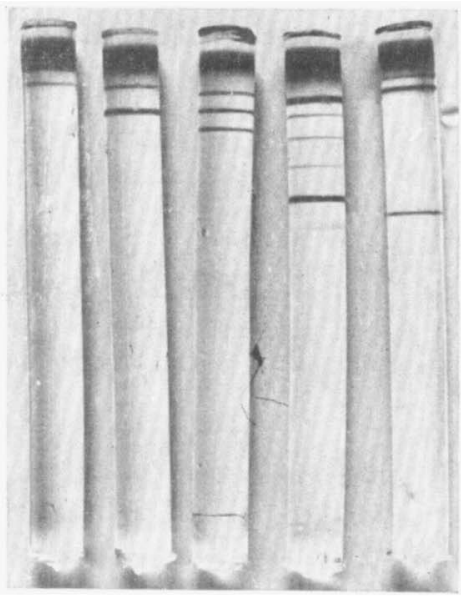

(c)

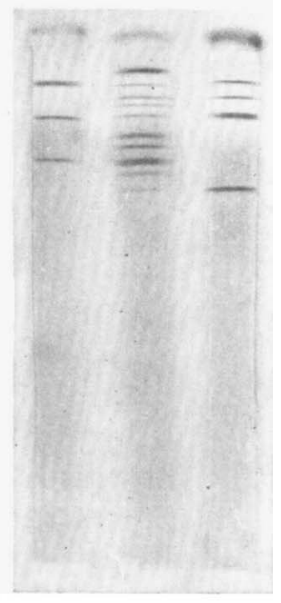

(d)

Fig. 7. PAGE separations corresponding to the insets of (a) Fig. 3, (b) Fig. 4, (c) Fig. 5 and (d) Fig. 6.

glucanases and by the endoglucanases released in the shock fluid I (Fig. 5a). Aryl I and aryl II also hydrolysed the carboxymethylcellulose. All three aryl- $\beta$-glucosidases, but none of the endoglucanases, hydrolysed cellobiose. Cellobiose was the only substrate hydrolysed by aryl III.

\section{DISCUSSION}

Unlike fungi, where all components of the cellulase complex are released into the culture medium (Berg \& Pettersson, 1977), bacteria seem to release only endoglucanases. This was found with Cellvibrio vulgaris (Oberkotter \& Rosenbergh, 1978), Cellulomonas sp. (Beguin \& Eisen, 1978) and Pseudomonas fluorescens var. cellulosa (Yamane et al., 1971). In the latter 
Table 2. Hydrolytic products obtained from different substrates after incubation with fractionated enzymes

Three $\mathrm{ml}$ each of substrate, buffer and diluted enzyme (200 $\mu \mathrm{g}$ protein) were incubated for $1 \mathrm{~h}$ and the products released were detected by paper chromatography. For details, see Methods.

\begin{tabular}{|c|c|c|c|}
\hline \multirow[b]{2}{*}{ Enzyme fraction } & \multicolumn{3}{|c|}{ Sugars released from: } \\
\hline & Avicel & $\begin{array}{l}\text { Carboxymethyl- } \\
\text { cellulose }\end{array}$ & Cellobiose \\
\hline \multicolumn{4}{|l|}{ Extracellular } \\
\hline Endoglucanase I & - & $\begin{array}{l}\text { Cellobiose, } \\
\text { cellotriose }\end{array}$ & $\cdots$ \\
\hline Endoglucanase II & 一 & $\begin{array}{l}\text { Cellobiose, } \\
\text { cellotriose, } \\
\text { cellotetraose }\end{array}$ & 一 \\
\hline \multicolumn{4}{|l|}{ Cell-bound } \\
\hline Endoglucanases & 一 & $\begin{array}{l}\text { Cellobiose, } \\
\text { cellotriose, } \\
\text { cellotetraose }\end{array}$ & - \\
\hline Aryl- $\beta$-glucosidase I & - & $\begin{array}{l}\text { Glucose }(\mathrm{tr}), \\
\text { cellobiose }\end{array}$ & Glucose (tr) \\
\hline Aryl- $\beta$-glucosidase II & - & Glucose & Gilucose \\
\hline Aryl- $\beta$-glucosidase III & $\rightarrow$ & - & Glucose \\
\hline
\end{tabular}

-, No sugars detected; $(\mathrm{tr})$, trace.

two micro-organisms, three types of endoglucanases were found. In our studies also, only the endoglucanases were extracellular, but only two types of activity were found. Moreover, part of the endoglucanase activity was cell-bound. Cell-bound activity was also observed after growth on cellobiose, whereas no extracellular activity was detected. An interesting finding was the presence of endoglucanase in shock fluid-stage I after growth on cellulose and in shock fluid-stage II after growth on cellobiose. Thus for growth on cellulose, the cell-bound endoglucanase might have been localized more externally than for growth on cellobiose and released together with the lipopolysaccharide (Heppel, 1971). In the absence of EDTA there was no release of enzymes in stage I. Cytoplasmic endoglucanase was also present and its activity was the same after growth on cellulose or on cellobiose. PAGE indicated that the cytoplasmic endoglucanase activity was found in the same protein band that showed aryl- $\beta$-glucosidase $I$ activity. This protein band was different from the band containing the endoglucanase obtained with shock fluid or after spheroplast formation. Moreover, the latter did not show any aryl- $\beta$-glucosidase activity. Thus it is very likely that cytoplasmic endoglucanase is different from periplasmic endoglucanase. Since aryl- $\beta$ glucosidase II also possessed endoglucanase activity, it seems that at least three cell-bound enzymes must have endoglucanase activity. The relationship with the two extracellular enzymes cannot be established at present.

Aryl- $\beta$-glucosidases were always cell-bound. Two enzymes were present in the periplasmic space and one was cytoplasmic. The two periplasmic enzymes were located differently. Aryl- $\beta$-glucosidase III was extracted in shock fluid-stage I and aryl- $\beta$-glucosidase II in stage II. For cellulose-grown organisms there was more aryl II than aryl III. With growth on cellobiose the amount of aryl- $\beta$-glucosidase III increased. Aryl- $\beta$-glucosidase III was the only enzyme that did not hydrolyse carboxymethylcellulose but it did hydrolyse cellobiose. Thus it seems that during growth on a particular substrate (cellulose or cellobiose) those enzymes that are necessary for its breakdown are located more externally. Endoglucanase was more external for growth on cellulose than for growth on cellobiose. For growth on cellobiose the more external aryl- $\beta$-glucosidase III increased in activity.

Yamane et al. (1971) and Hwang \& Suzuki (1976) did not detect $\beta$-glucosidases in the 
Cellulose

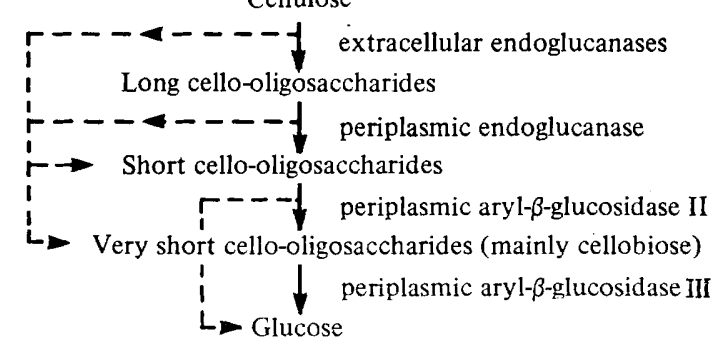

Fig. 8. Suggested scheme for cellulose breakdown.

shock fluid of $P$. fluorescens var. cellulosa but they found membrane-bound and cytoplasmic enzymes. In our experiments one aryl- $\beta$-glucosidase was also cytoplasmic. It differed from the periplasmic enzymes in releasing cellobiose from carboxymethylcellulose, and in hydrolysing cellobiose much less efficiently. Lower amounts of this enzyme were formed after growth on cellobiose than on cellulose.

After osmotic shock treatment and cell rupture with the French press, further breakage using the Braun disruptor and glass beads resulted in the detection of more aryl- $\beta$-glucosidases II and III. Possibly these residual amounts of enzyme were bound more tightly in the periplasm. When spheroplasts were formed, about $20 \%$ of the cells remained intact. Thus when the residue after plasmoptysis was further broken with the Braun disruptor and glass beads it was usual to find not only aryl- $\beta$-glucosidases II and III but also I.

It is interesting to note that glucose is released from cellobiose mainly by aryl- $\beta$-glucosidase III which is located more externally in the periplasm and whose activity increases after growth on cellobiose. This enzyme may be needed mainly for the hydrolysis of cellobiose, formed from cellulose and lower cello-oljgosaccharides, into glucose. Aryl- $\beta$-glucosidase II also releases glucose from carboxymethylcellulose. It is also periplasmic and its activity increases after growth on cellulose. It may be mainly responsible for the breakdown of cellooligosaccharides, arising from cellulose, into cellobiose and glucose. The endoglucanase that is found in the periplasm becomes more external after growth of the bacteria on cellulose. It may be needed especially for the further breakdown of long cello-oligosaccharides formed from cellulose by the endoglucanases excreted into the medium. These latter enzymes are especially synthesized during growth on cellulose. Very low amounts, however, are always found and these may be sufficient to release from the insoluble cellulose the necessary soluble molecules for induction of these extracellular endoglucanases. Nothing can be said at present on the function of the cytoplasmic endoglucanase (aryl- $\beta$-glucosidase I). These ideas about cellulose breakdown are illustrated in Fig. 8.

Many questions remain unresolved; these include the nature of the inducing molecule for the synthesis of extracellular endoglucanases, the fundamental reasons for the different locations of some of the enzymes (mainly the periplasmic endoglucanase), the function of the intracellular endoglucanase and, most important, the failure of the extracted enzyme to hydrolyse avicel or other native cellulose.

\section{REFERENCES}

Beguin, P. \& Eisen, H. (1978). Purification and partial characterization of three extracellular cellulases from Cellulomonas sp. European Journal of Biochemistry 87, 525-531.

BerG, B. (1975). Cellulase location in Cellvibrio fulvus. Canadian Journal of Microbiology 21, 51-57.
Berg, B. \& Pettersson, G. (1977). Location and formation of cellulase in Trichoderma viride. Journal of Applied Bacteriology 42, 65-75.

Berg, B., v. Hofsten, B. \& Pettersson, G. (1972). Growth and cellulase formation in Cellvibrio fulvus. Journal of Applied Bacteriology 35, 201214. 
Bevers, J. (1976). Biochemistry of the breakdown of cellulose by cellulolytic bacteria isolated from waste water treatment units. Agricultura 22, 1-115.

Cooper, C. M., Fernstrom, G. A. \& Miller, S. A. (1944). Performance of agitated gas-liquid contactors. Industrial and Engineering Chemistry 36, 504-509.

Heppel, L. A. (1971). The concept of periplasmic enzymes. In Structure and Function of Biological Membranes, pp. 224-247. Edited by L. I. Rothfield. New York \& London: Academic Press.

Hwang, J. T. \& Suzuki, H. (1976). Intracellular distribution and some properties of $\beta$-glucosidases of a cellulolytic pseudomonad. Agricultural and Biological Chemistry 40, 2169-2175.

Kowit, J. D., Choy, W., Champe, S. P. \& GoldBERG, A. L. (1976). Role and location of protease I from Escherichia coli. Journal of Bacteriology 128, 776-782.

Nelson, N. (1944). A photometric adaptation of the Somogyi method for the determination of glucose. Journal of Biological Chemistry 153, 375-380.

Oberkotter, L. V. \& Rosenbergh, F. A. (1978). Extracellular $\beta$-endo-1,4-glucanases in Cellvibrio vulgaris. Applied and Environmental Microbiology 36, 205-209.

Ramasamy, K., Prakasam, K., Bevers, J. \&VerachTERT, H. (1979). Production of bacterial proteins from cellulosic materials. Journal of Applied Bacteriology 46, 117-124.

REese, E. T. (1977). Degradation of polymeric carbohydrates by microbial enzymes. Recent Advances in Phytochemistry 11, 311-365.
Selby, K. \& Maitland, C. C. (1965). The fractionation of Myrothecium verrucaria cellulase by gel filtration. Biochemical Journal 94, 578-583.

Trevelyan, W. E., Procter, D. P. \& Harrison, J. S. (1950). Detection of sugars on paper chromatograms. Nature, London 166, 444-445.

Van Oevelen, D., Bevers, J. \& Verachtert, H. (1975). Study of the influence of dyes on the biodegradation of coloured papers. Environmental Pollution 9, 193-210.

Verachtert, H. \& Ramasamy, K. (1979). In vivo cellulose degradation in activated sludge units. U.S. Japan Inter Society Microbiology Congress/ 79th ASM Annual Meeting, Honolulu, Hawaii, p. 238 (abstract).

Verachtert, H., Ramasamy, K., Deschuttere, P. \& BeVers, J. (1978). Rapid method for the direct observation of aryl- $\beta$-glucosidases after separation on polyacrylamide gel. Journal of Chromatography 147, 443-445.

Woon, T. M. (1968). Cellulolytic enzyme system of Trichoderma koningii. Separation of components attacking native cotton. Biochemical Journal 109, 217-227.

Yamane, K., Suzuki, H. \& Nisizawa, K. (1970). Purification and properties of extracellular and cell-bound cellulase components of Pseudomonas fluorescens var. cellulosa. Journal of Biochemistry 67, 19-35.

Yamane, K., Yoshikawa, T., Suzuki, H. \& Nisizawa, K. (1971). Localization of cellulase components in Pseudomonas fluorescens var. cellulosa. Journal of Biochemistry 69, 771-778. 